\title{
Timing, Logistics and Bureaucratic Process in Planning an Experimental In Vivo Nerve Regeneration Project from A to Z
}

Andrei MARIN', Georgiana Gabriela MARIN², Anca PATEA ${ }^{4}$, Dan Mircea ENESCU³

\begin{abstract}
Every research project begins with an idea and a theory. After a thorough examination of previous publications related to the idea (in order not to re-invent the wheel), the idea must be put in practice to test the hypothesis. When it comes to in vivo experiments, there are several bureaucratic demands which need to be fulfilled before commencing any project. Furthermore, the experiments require similar clinical conditions for surgery and postoperative care in order to obtain irrefutable results. Apart from the logistics necessary for the surgical intervention and the postoperative care, logistics referring to proper accommodation and food supplies for the animals to be experimented on is also to be considered from the beginning. Last but not least, the human resource is most valuable in such projects, as the surgical interventions are time consuming and require for sterile conditions at least 2 people (the surgeon and the assistant). The personnel involved in the project needs to allocate time for the postoperative care, the following clinical tests as well as the daily time spent for cleaning, feeding and providing water for the animals in the study. In nerve regeneration studies, this can take up to months, therefore all the resources should be well planned before the beginning of the project.
\end{abstract}

Keywords: project, animal experimentation, resources, timing.

\section{Rezumat}

Orice proiect de cercetare începe cu o idee sau o teorie. După o examinare riguroasă a publicațiilor anterioare pe tema respectivă (pentru a nu reinventa roata), ideea trebuie pusă în practică pentru a testa ipoteza. Când avem de-a face cu experimente in vivo, există și o serie de cerințe birocratice care trebuie îndeplinite înainte de începerea unui astfel de proiect. Experimentele necesită și condiții clinice similare pentru operație și îngrijire postoperatorie, logistică - însemnând condiții de cazare și mấncare pentru animalele luate în studiu. Nu în ultimul rând, resursa umană este extrem de valoroasă în astfel de proiecte, întrucât intervențiile chirurgicale sunt consumatoare de timp, necesitând condiții sterile și cel puțin 2 persoane implicate (operatorul și asistentul). Personalul implicat în proiect trebuie să aloce timp și îngrijirilor postoperatorii, testelor clinice ce urmează a fi efectuate, dar și pentru asigurarea apei, hranei și curăteniei animalelor din studiu. Când vorbim de regenerare nervoasă, acest proces poate dura chiar luni de zile; așadar toate resursele trebuie bine planificate înainte de începerea proiectului.

Cuvinte cheie: proiect, experimentare pe animale, resurse, timing.

\footnotetext{
1 Department of Plastic Surgery, „Bagdasar Arseni” Emergency Hospital, Bucharest, Romania

2 Department of Cardiology, „Prof. Dr. C.C. Iliescu” Emergency Institute for Cardiovascular Diseases, Bucharest Romania

${ }^{3}$ Department of Plastic Surgery, „Grigore Alexandrescu" Pediatric

Emergency Hospital, Bucharest, Romania

${ }^{4}$ University of Veterinary Medicine, Bucharest, Romania
}

\section{Corresponding author:} Andrei MARIN, Department of Plastic Surgery, „Bagdasar Arseni” Emergency Hospital, Romania. E-mail: marin_dpt@yahoo.com 


\section{INTRODUCTION}

A $\mathrm{PhD}$ thesis is the perfect motivation in developing an idea for a research project. My idea consisted in a comparison between 4 different nerve repair types for a $0,5 \mathrm{~cm}$ sciatic nerve defect ${ }^{1}$. The 4 batches are: nerve autograft ${ }^{2}$, vascular conduct $t^{3-5}$, vascular conduct with PRP (platelet rich plasma ${ }^{6-9}$ ) and vascular conduct with stem cell ${ }^{10-13}$. After a thorough analysis on similar publications, I realized there were no such studies done before, so that this subject had the principle of novelty. There are many similarities between the rat nerve and the human peripheral nerve, therefore the choice for Wistar rats is a suitable one for the experiment.

After writing down the description of the project, the bureaucratic process begins by obtaining approvals from the Ethics Commission and the Sanitary Veterinary Department when using animal subjects in experimental projects. A collaboration protocol for using a laboratory and proper spaces for postoperative tests is mandatory. Furthermore, a protocol with the veterinary doctor for anesthesia, postoperative medicine and euthanasia is also required. When referring to timing, all these documents require at least one month for approval after they have been submitted.

During this month, the planning and preparation imply gathering all the logistics necessary for the lodging and accommodation of the rats, for the surgical operating room, finding the apparatus necessary for all interventions (operative microscope, centrifuge, stem cell container), making the time schedule for the operations in order to have the personnel needed, creating the observation papers for each rat in each bunch, preparing the cages and tunnels for the postoperative clinical tests and finding the food and shavings supplier for the entire duration of the project. Finally, at the end of the project (3 months after the intervention), histological and imagistic (MRI $)^{14}$ examinations for the repaired nerves are foreseen and should be also be planned with a histopathologist and a radiologist.

\section{MATERIAL AND METHODS}

For this project a number of 40 male Wistar rats divided into 4 batches will be used. As biological materials, in the first bunch the nerve autograft will be harvested
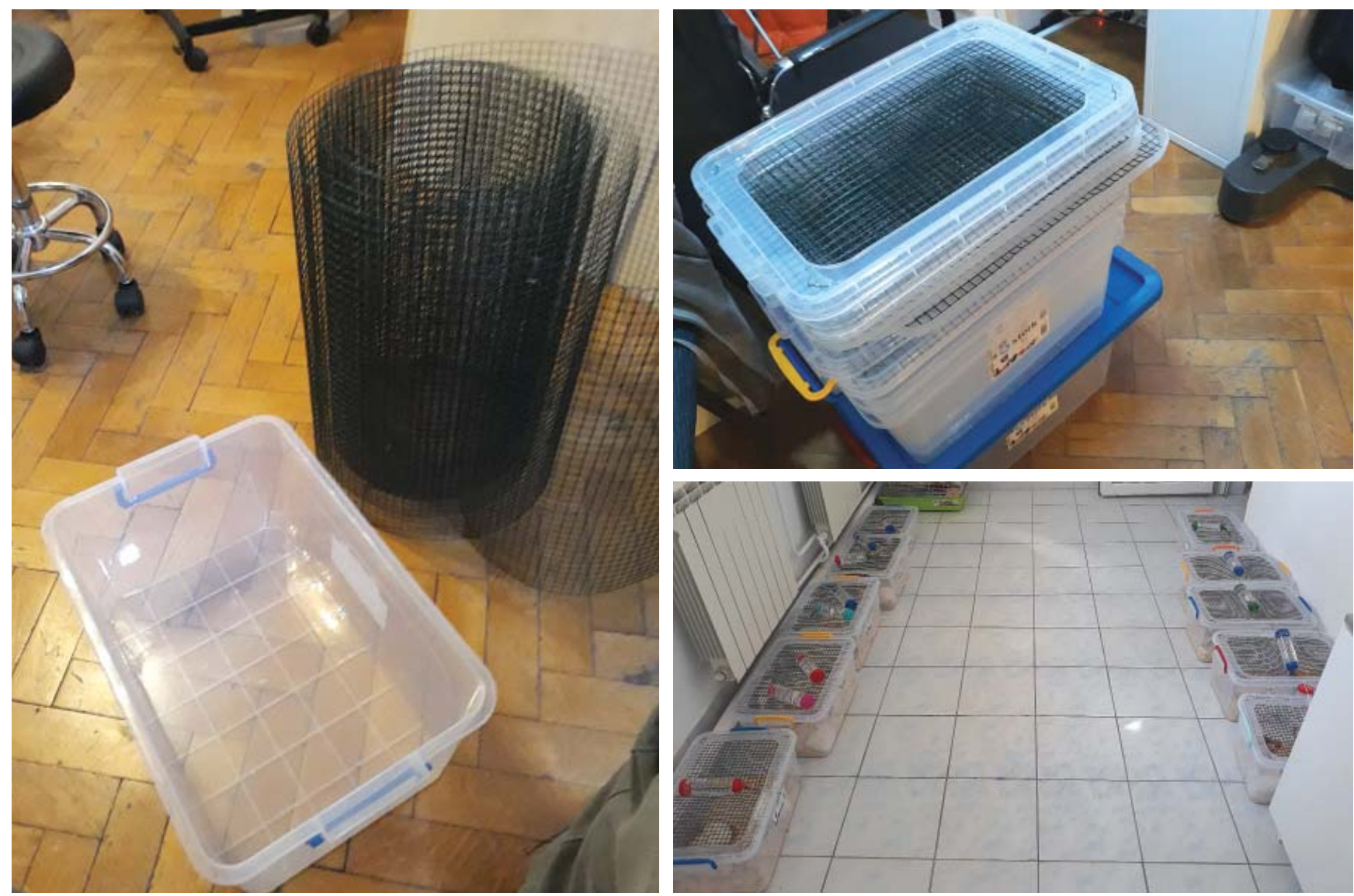
and sutured back into its original place. The $2^{\text {nd }}, 3^{\text {rd }}$ and $4^{\text {th }}$ bunch require a vascular conduct to replace the nerve defect - therefore in order not to operate the same rat at 2 different sites, 2 separate Wistar rats will be sacrificed to obtain blood for the PRP as well as for harvesting vascular conducts (rat aorta). Therefore all batches will be inflicted with a iatrogenic $5^{\text {th }}$ degree Sunderland nerve injury, which will be handled differently. ${ }^{15,16}$

For lodging, a number of 20 plastic cages divided by a plastic transparent separator are created. Each cage will host 2 rats which will be separated by a transparent plastic material in order to prevent cannibalism. In the separator at the top, there is a small opening in which
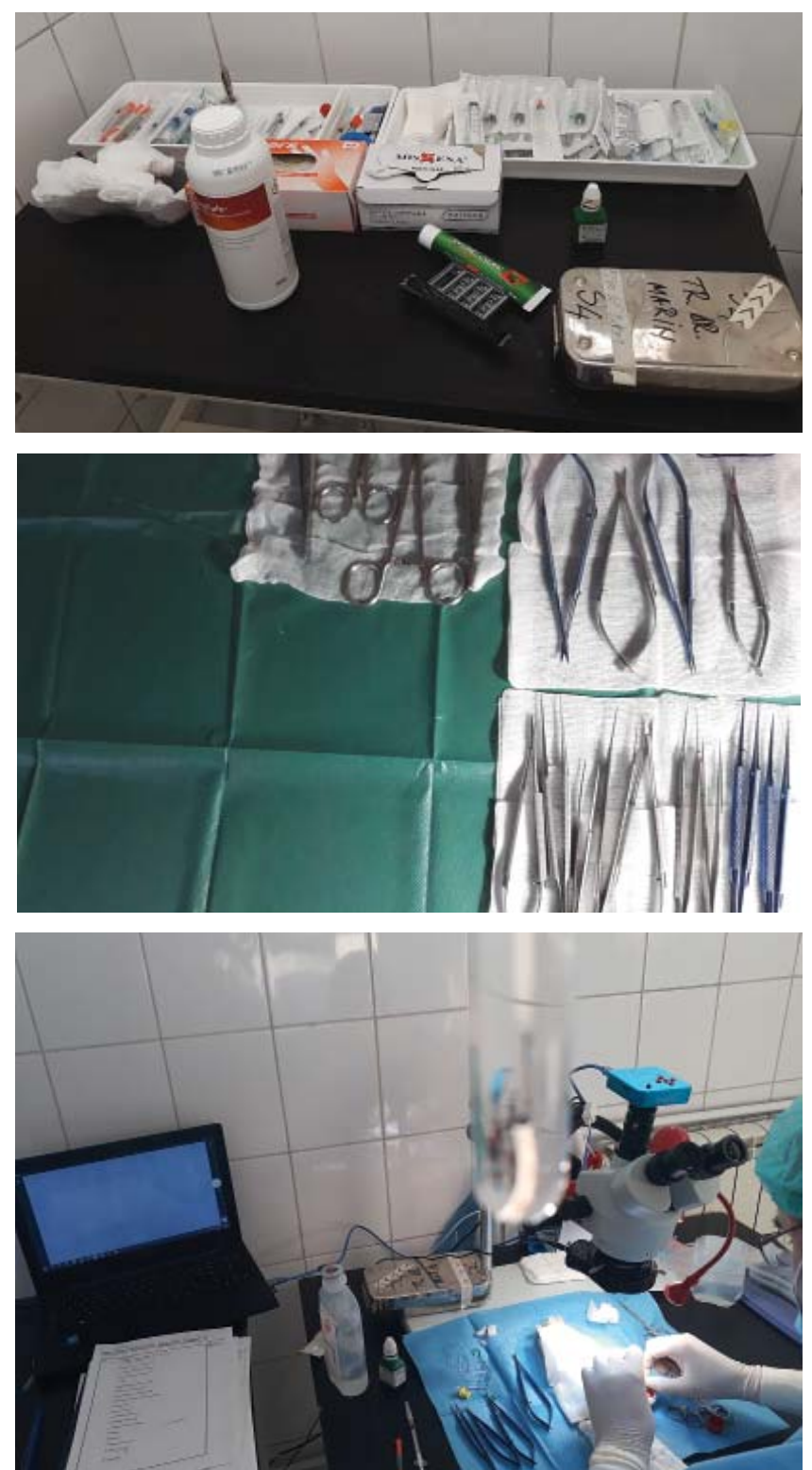

the drinking device is placed so that both rats can reach it.

The logistics for the operating room includes a surgical microscope, an adjustable chair, micro-surgical instruments, sterile drapes and other sterile supplies for general surgery interventions (sutures, macro surgical instruments, dressings, gloves, scalpel blades), laptop for recording of a surgical procedure and camera for taking photos of the key moments. For the preparation of the surgical site, the rat must be shaved prior to the operation and shaving devices are important to be sharp and effective in order to reduce the anesthesia time.
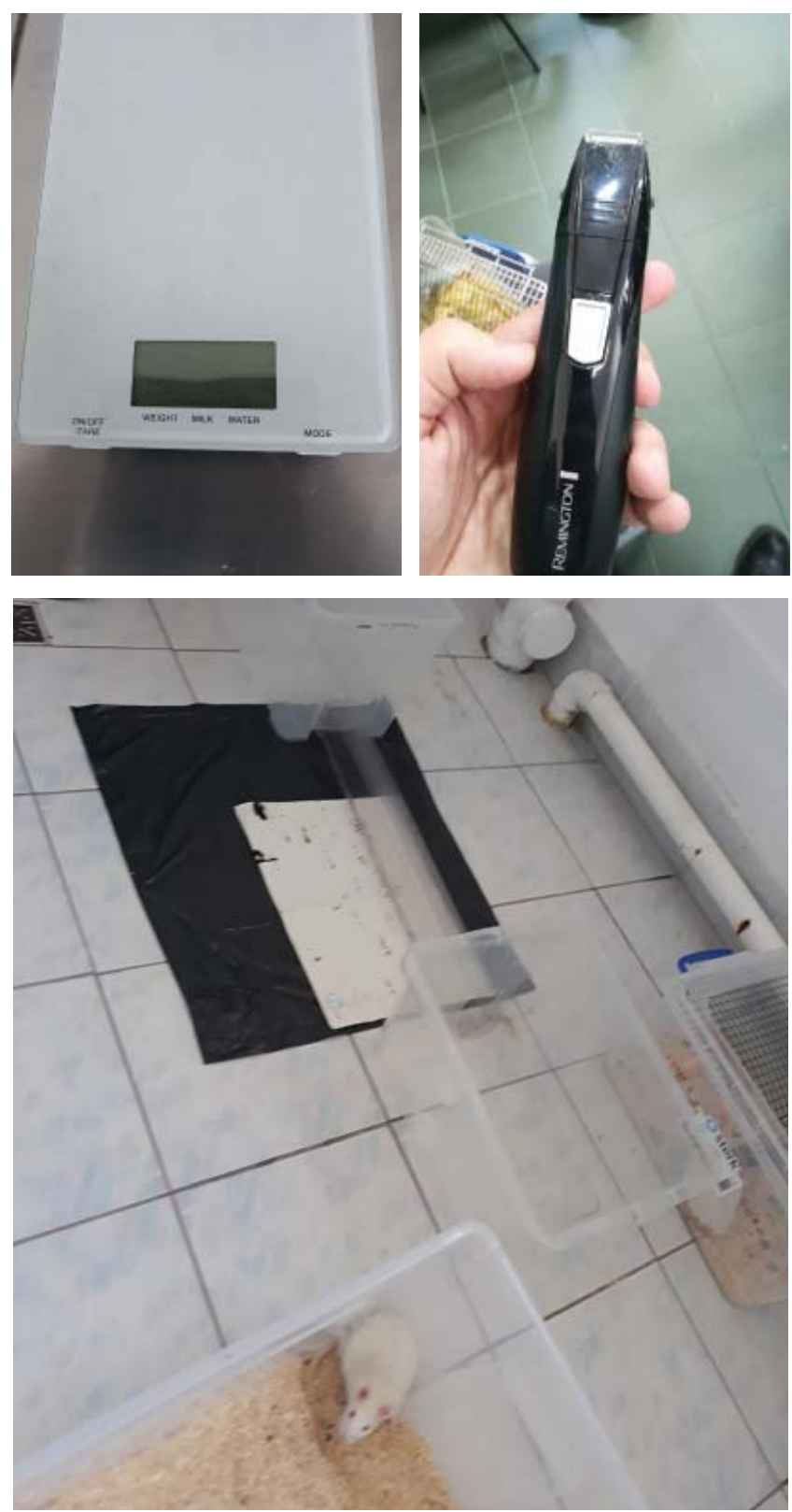
For the postoperative monitoring, as well as for the measurements prior to the operations, an electronic scale in grams is to be used. For the plantar recording, a transparent tunnel between 2 plastic cages is conceived.

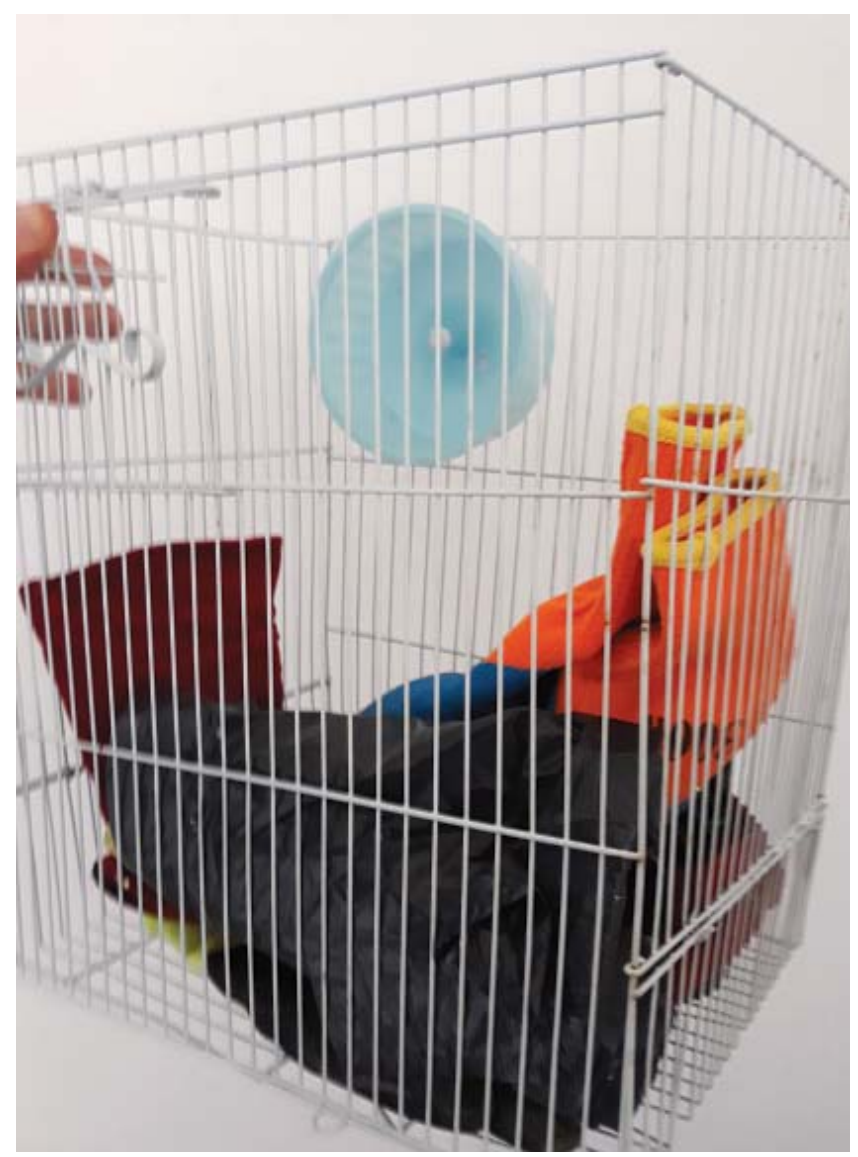

For all operations, a step by step file is designed and used for each rat. This has great importance: to monitor the times needed ${ }^{17}$ for each step of the intervention, to teach the new assistants the tasks which they need to fulfill and to monitor each rat. For clinical evaluation of the sensitivity of the inferior limb, a cage with bars is needed. This makes it easy for the foot to fall between the bars and can be pinched with an anatomical forceps at different levels to test the sensitivity.

For the $3^{\text {rd }}$ and $4^{\text {th }}$ batches - the PRP batch and the stem cell batch, protocols for obtaining these factors are needed. Both protocols require a small centrifuge. For the PRP, special tubes for blood harvesting are required, while the frozen stem cells in liquid nitrogen require transport in special container.

This container has enough liquid nitrogen to keep the cells at $-196^{\circ}$ Celsius for $2-3$ days and once defros-
An ink pad and ink (or betadine) can be used to color the foot prints of the rat before walking on an absorbing paper.

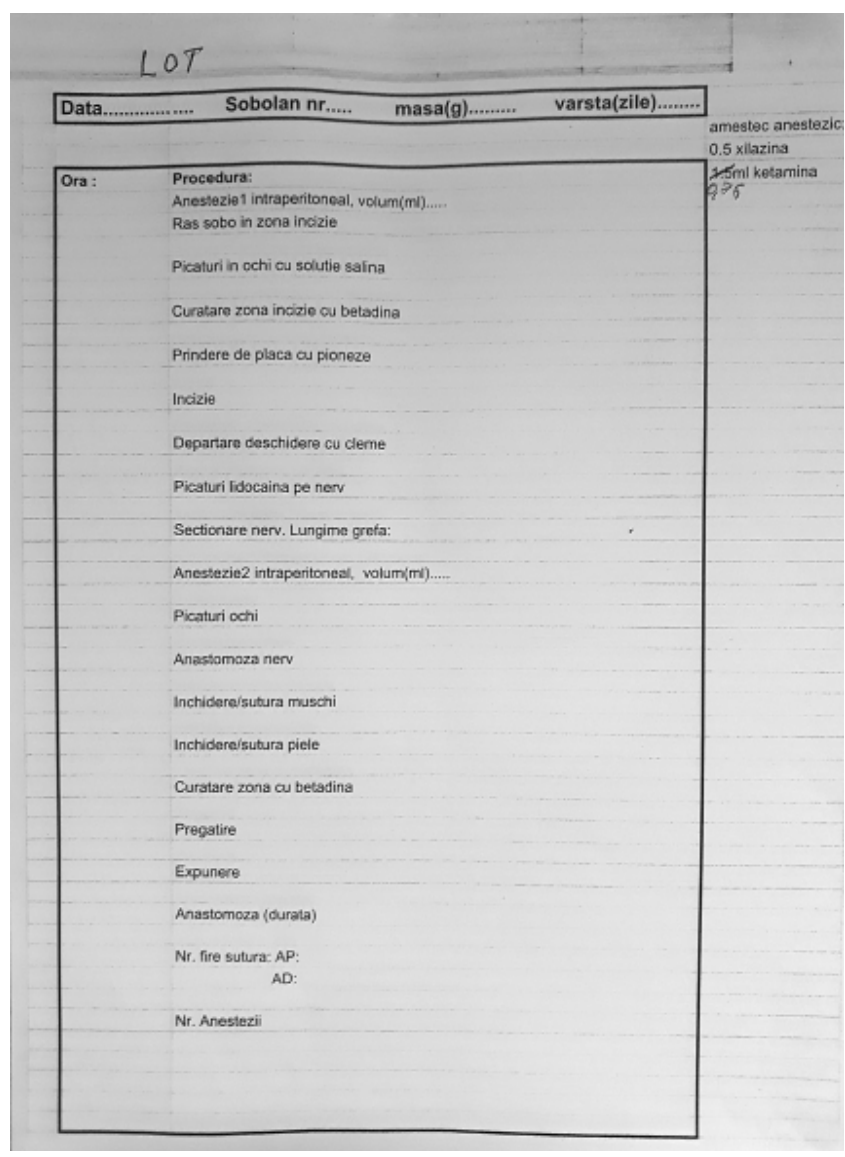

ted, they need to be transplanted in maximum 6 hours. For the experiment, 2 separate tubes with stem cells will be required (2 days with 5 operations in 5-6 hours each day) as well as 2 tubes with PRP ( 2 days with 5 operations in 5-6 hours). A PBS solution used in the defrosting protocol of the stem cells is mandatory, as the liquid nitrogen can affect these cells immediately after they are taken out of the special container.

For the anesthesia protocol, a mixture of ketamine $75 \mathrm{mg} / \mathrm{kg}$ and xylazin $10 \mathrm{mg} / \mathrm{kg}$ is to be administered intraperitoneal. For supplementary intraoperative pain control, lidocaine will be applied directly on the nerve before transection.

Postoperative anti-inflammatory medicine (meloxicam $-0.04 \mathrm{ml}$ ) and antibiotics (enroxil $-0,02 \mathrm{ml}$ ) are to be injected subcutaneous for 3 days. Betadine and baneocin ointment are for local use of the wound care. 

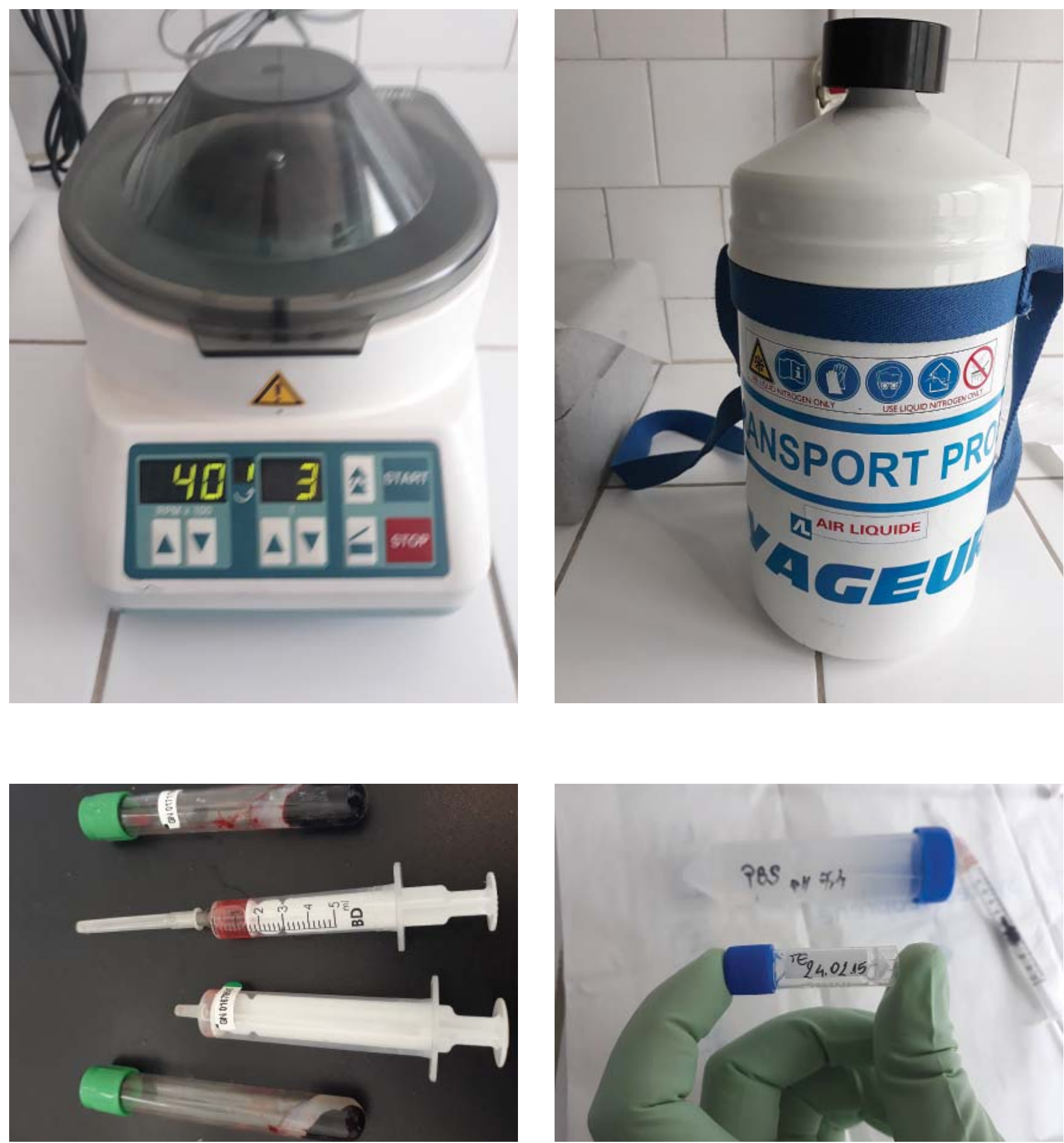

Osteocicatrat is to be used for the prevention of selfmultilation.

All the above mentioned medicine are to be purchased (the anesthesia medicine require a prescription from the veterinary anesthetist) and the quantities should be calculated for 40 rats plus the 2 rats which will

be sacrificed. The medicine, which requires low temperature storage, should also be transported in special bags that keep the low temperature.

Last but not least - for a good recovery, a good microclimate requires fresh shavings, good food supplies - pellet, fruits and vegetables (bananas, carrots, apples, 

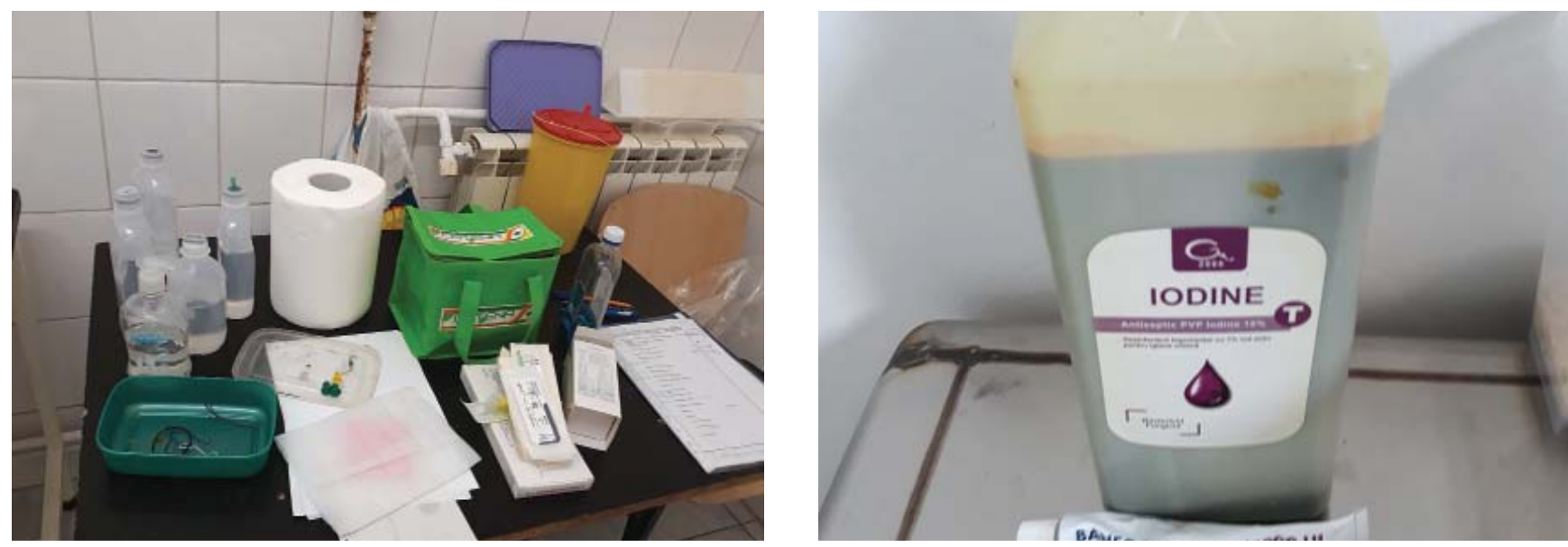

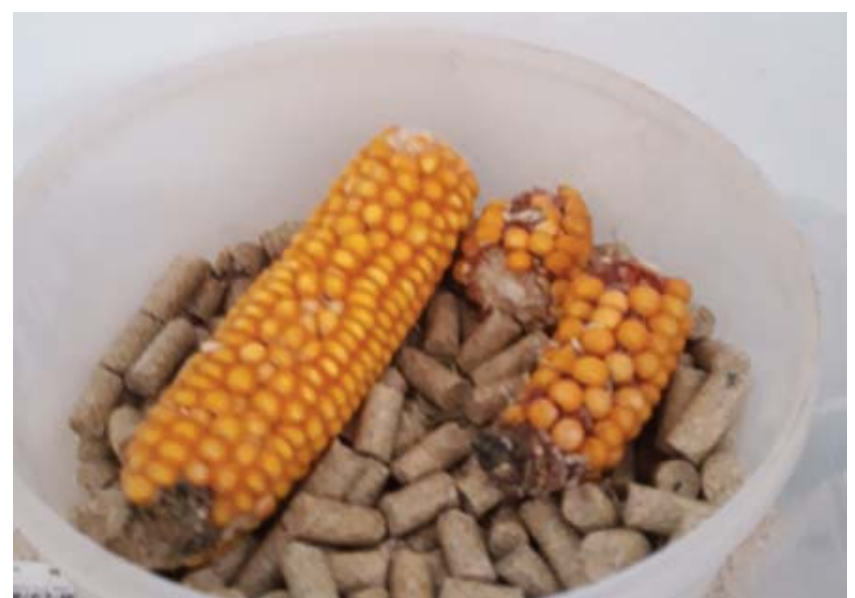

corn), fresh water and normal environmental temperatures. The animals are fed daily, the shavings are changed every other day.

\section{CONCLUSIONS}

An experimental in vivo project requires funds, time and human resources. Each of them is very important, they are all interchangeable (but the human resource is indispensable and can affect in a positive or a negative way the outcome of the project). Such experiments require several approvals, therefore time-management is an important factor when initiating them.

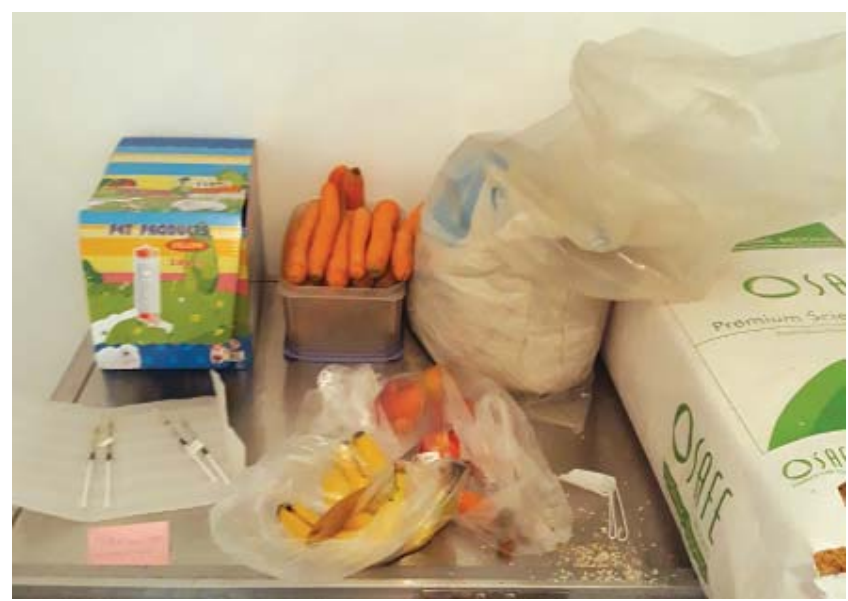

Good coordination, planning and management are the key to a successful project, while the lack of these features can lead to postponing the moments in the project, possibly compromising the results.

\section{Compliance with ethics requirements:}

The authors declare no conflict of interest regarding this article.

The authors declare that all the procedures and experiments of this study respect the ethical standards in the Helsinki Declaration of 1975, as revised in 2008(5), as well as the national law. Informed consent was obtained from all the patients included in the study. 
Timing, Logistics and Bureaucratic Process in Planning an Experimental In Vivo Nerve Regeneration Project from A to Z

\section{References}

1. Battiston B, Titolo P, Ciclamini D, Panero B. Peripheral Nerve Defects: Overviews of Practice in Europe. Hand Clin. 2017 Aug;33(3):545-550. doi: 10.1016/j.hcl.2017.04.005. Review.

2. Sabongi RG, De Rizzo LA, Fernandes M, Valente SG, Gomes dos Santos JB, Faloppa F, Leite VM. Nerve regeneration: is there an alternative to nervous graft? J Reconstr Microsurg. 2014 Nov;30(9):607-16. doi: 10.1055/s-0034-1372477. Epub 2014 Aug 4.

3. Safa B, Buncke G. Autograft Substitutes: Conduits and Processed Nerve Allografts. Hand Clin. 2016 May;32(2):127-40. doi: 10.1016/j.hcl.2015.12.012. Review.

4. Lin MY, Manzano G, Gupta R. Nerve allografts and conduits in peripheral nerve repair. Hand Clin. 2013 Aug;29(3):331-48. doi: 10.1016/j.hcl.2013.04.003. Review.

5. Li CY, Cao DC. [Experimental study on repair of peripheral nerve defect by basic fibroblast growth factor combined with autogenous vein graft conduit]. Zhongguo Xiu Fu Chong Jian Wai Ke Za Zhi. 2000 Jan;14(1):14-6

6. Ikumi A, Hara Y, Yoshioka T, Kanamori A, Yamazaki M.Effect of local administration of platelet-rich plasma (PRP) on peripheral nerve regeneration: An experimental study in the rabbit model. Microsurgery. 2018 Mar;38(3):300-309. doi: 10.1002/ micr.30263. Epub 2017 Nov 2.

7. Teymur H, Tiftikcioglu YO, Cavusoglu T, Tiftikcioglu BI, Erbas O, Yigitturk G, Uyanikgil Y. Effect of platelet-rich plasma on reconstruction with nerve autografts.

Kaohsiung J Med Sci. 2017 Feb;33(2):69-77. doi: 10.1016/j. kjms.2016.11.005. Epub 2016 Dec 29

8. Sánchez M, Anitua E, Delgado D, Sanchez P, Prado R, Orive G, Padilla S. Platelet-rich plasma, a source of autologous growth factors and biomimetic scaffold for peripheral nerve regeneration. Expert Opin Biol Ther. 2017 Feb;17(2):197-212. doi: 10.1080/14712598.2017.1259409. Epub 2016 Nov 28. Review

9. Bastami F, Vares P, Khojasteh A. Healing Effects of Platelet-Rich Plasma on Peripheral Nerve Injuries. J Craniofac Surg. 2017 Jan;28(1):e49-e57. doi: 10.1097/SCS.0000000000003198. Review.
10. Jiang L, Jones S, Jia X. Stem Cell Transplantation for Peripheral Nerve Regeneration: Current Options and Opportunities. Int J Mol Sci. 2017 Jan 5;18(1). pii: E94. doi: 10.3390/ijms18010094. Review.

11. Lee DC, Chen JH, Hsu TY, Chang LH, Chang H, Chi YH, Chiu IM. Neural stem cells promote nerve regeneration through IL12induced Schwann cell differentiation. Mol Cell Neurosci. 2017 Mar;79:1-11. doi: 10.1016/j.mcn.2016.11.007. Epub 2016 Nov 16

12. Guo J, Guo S, Wang Y, Yu Y. Promoting potential of adipose derived stem cells on peripheral nerve regeneration. Mol Med Rep. 2017 Nov;16(5):7297-7304. doi: 10.3892/mmr.2017.7570. Epub 2017 Sep 21

13. Mohamadi F, Ebrahimi-Barough $S$, Nourani MR, Mansoori $K$, Salehi M, Alizadeh AA, Tavangar SM, Sefat F, Sharifi S, Ai J. Enhanced sciatic nerve regeneration by human endometrial stem cells in an electrospun poly ( $\varepsilon$-caprolactone)/collagen/ NBG nerve conduit in rat. Artif Cells Nanomed Biotechnol. 2018 Dec;46(8):1731-1743. doi: 10.1080/21691401.2017.1391823. Epub 2017 Nov 8.

14. Chhabra A, Ahlawat S, Belzberg A, Andreseik G. Peripheral nerve injury grading simplified on MR neurography: As referenced to Seddon and Sunderland classifications. Indian J Radiol Imaging. 2014 Jul;24(3):217-24. doi: 10.4103/0971-3026.137025

15. Andrei, M., loana, M., \& Mircea, E. (2019). Underlying histopathology of peripheral nerve injury and the classical nerve repair techniques. Romanian Neurosurgery, 33(1), 17-22. https://doi. org/10.33962/roneuro-2019-003

16. Flores AJ, Lavernia CJ, Owens PW. Anatomy and physiology of peripheral nerve injury and repair. Am J Orthop (Belle Mead NJ). 2000 Mar;29(3):167-73. Review.

17. Marin Andrei, Marin Georgiana Gabriela, Dobrete Nicoleta Amalia, Enescu Dan Mircea. Learning curve in rat dissection for experimental sciatic nerve repair. Romanian Neurosurgery (2019) XXXIII (3) September 2019. www.journals.lapub.co.uk/index. php/roneurosurgery 
